\title{
ALFABETSKA IN FUNKCIONALNA (NE)PISMENOST
}

\section{POVZETEK}

Na podlagi mednarodne raziskave (Možina, 2000) o funkcionalni pismenosti iz leta 1998 je možno sklepati, da je funkcionalna nepismenost Slovencev zaskrbljujoča. Raziskava je pokazala, da zgolj trije odstotki ljudi dosegajo 4. in 5. raven pri besedilni pismenosti, pet odstotkov jih to dosega pri dokumentacijski in slabih 10 odstotkov pri računski pismenosti. Minimalno raven, ki omogoča delovanje v sodobni tehnološki družbi, dosega še nadaljnjih 20 odstotkov, kar pomeni, da je 70 odstotkov slovenskega prebivalstva nezmožnega, da bi se primerno odzivalo na razmere okolja in samostojno reševalo probleme na osnovi razumevanja osnovnih vsakodnevnih življenjskih situacij. Nekateri pokazatelji funkcionalne nepismenosti ljudi se pojavijo npr. pri razumevanju voznega reda, tvorjenju krajših ali daljših besedil (dopisi, pisma, prošnje, sporočila), upoštevanju navodil ali branju lekarniških pojasnil, razumevanju svojih bolezni, odločanju o načinu zdravljenja, uporabi medijev, sodobne tehnologije itd. Reševanje problema funkcionalne nepismenosti se dotika dviga ravni splošne izobrazbe, socializacije posameznika in širjenja socialne mreže, kar omogoča posamezniku socialno in akcijsko kompetenco, po drugi strani pa sledi trendom $v$ novih oblikah dela in preživetja pod vplivom globalizacije, ki terja od posameznika vseživljenjsko izobraževanje in dvigovanje dodane vrednosti delovnega mesta. Funkcionalno nepismene osebe so zaostale v osebnostnem razvoju in niso sposobne, da prevzamejo odgovornost za svoje vseživljenjsko izobraževanje. Zato se same ne morejo izkopati iz stanja, v katerem je njihov razvoj obstal.

Ključne besede: alfabetska pismenost, funkcionalna pismenost, socializacija, vseživljenjsko izobraževanje, dodana vrednost delovnega mesta, socialna mreža

$\mathrm{N}$ fabetsko pismenost in funkcionalno pismenost, ker se $\mathrm{v}$ različnih pisnih virih pri nas kaže težnja, da se izraz »funkcionalna« izpušča in se uporablja samo izraz pismenost, vendar se na ta način v slovenskem jeziku in slovenskem pojmovnem svetu pojav bistveno zamegli. Poenostavljanje gre pripisati vplivom prevodov iz tuje literature, kjer sicer včasih uporabljajo samo izraz pismenost (ang. literacy), ker o analfabetizmu že zdavnaj ne govorijo več. Če upoštevamo pismenost $\mathrm{v}$ svetovnih razmerjih, poznajo izraz »alfabetizem«, ki pomeni temeljno pismenost (poznavanje črk in številk). Ker smo v Sloveniji odpravili analfabetizem že $\mathrm{v}$ drugi polovici 19. stoletja in se $\mathrm{z}$ dejansko nepismenostjo nismo več ukvarjali, sta zamrla izraza analfabetizem in analfabet. $\mathrm{Z}$ izenačevanjem pismenosti in funkcionalne pismenosti se pri nas pojav funkcionalne pismenosti lahko zelo zamegli, to pa otežuje 
Alfabetska pismenost je problem nerazvitih držav, medtem ko za funkcionalno pismenost velja, da gre za problem razvitih držav in držav v razvoju. Funkcionalno nepismeni del prebivalstva pušča za seboj industrijsko obdobje. To so predvsem delavci, prej množično zaposleni v industriji na najnižjih delih, z zakrnelim osebnostnim razvojem, danes pa bi se morali znajti sami. Zahtevnejše delovne naloge je opravljala elita, menedžment, ljudje na vrhu družbene piramide so odločali tudi za one spodaj. Danes postaja nadaljnji ekonomski, socialni in kulturni razvoj odvisen zlasti od kvalitete in stopnje razvitosti širokih množic. Peščica intelektualne elite nastajajočih potreb ne more več zadovoljevati. Vsak narod bo našel v svetovnih razmerjih tisto mesto, ki mu pripada glede na nivo, na katerem lahko njegova populacija prebivalstva funkcionira. Zaposljivost posameznika in celih socialnih skupin je vedno bolj odvisna od človekove avtonomnosti in razvitih sposobnosti, s katerimi bo ta posameznik razpolagal (Krajnc, 1988, str. 147, 148).

odkrivanje dejansko funkcionalno nepismenih posameznikov. V slovenskem okolju ima nepismenost že svoj pomen, tj. stanje posameznika, ki ne zna ne brati in ne pisati, drugače je $v$ drugih jezikih, kjer obstajata dva izraza: analfabetizem za nepismenost in iletrizem za funkcionalno nepismenost (Krajnc, 2001, str. 60).

Danes smo priča nenehnemu tehnološkemu in znanstvenemu napredku, kar povzroča kulturno, socialno ter družbeno preobrazbo in s tem potrebe po novih znanjih, spretnostih in veščinah. Ena izmed teh veščin je vsekakor spretna uporaba in aplikacija pismenosti v raznih življenjskih situacijah, govorimo torej o funkcionalni pismenosti ljudi.

\section{ZNAČILNOSTI FUNKCIONALNO NEPISMENIH OSEB}

Funkcionalno nepismen posameznik zna brati ter pisati in se je tudi nekaj let šolal (v Sloveniji od štirih razredov osnovne šole do dve- ali triletne poklicne šole), vendar sta njegova razgledanost in znanje slaba, sposobnosti in potrebne osebnostne lastnosti pa so tako nizko razvite, da si z njimi ne more veliko pomagati (Krajnc, 2001, str. 60).

To so vsekakor osebe, ki imajo slabo spretnost branja, pisanja in računanja, ustnega izražanja in poslušanja $\mathrm{z}$ razumevanjem.
Težave se navzven pokažejo s tem, da ljudje ne znajo:

- izpolniti preprostega obrazca (položnica, plačilni ček, poštna nakaznica ...);

- tvoriti krajših in daljših besedil (obvestila, opravičila ...);

- uporabljati voznega reda (odhodi, prihodi, čas vožnje), zemljevida, avtokarte, grafikona, vremenske slike ...;

- prepoznati teme krajšega besedila ali razumeti različnih pisnih navodil, smiselno brati, ločiti bistveno od nebistvenega;

- uporabljati navodil in opozoril za jemanje zdravil;

- izračunati preprostih uporabnih matematičnih nalog;

- besedišča, ki spada k splošni razgledanosti (omejen je zgolj na nekaj preprostih besed);

- komunikacije, povezane $\mathrm{z}$ življenjskimi situacijami, ki so netipične za njihovo okolje, itd.

Funkcionalno nepismena oseba je najverjetneje imela probleme že v osnovni šoli, ima negativne izkušnje s šolanjem ter slab odnos do državnih in kulturnih institucij, ki se jih načeloma izogiba. Posameznike je pogosto sram in so zelo šibki v novih situacijah.

Iz navedenega sledi, da funkcionalno nepismene osebe zaradi pomanjkljivih spretnosti branja, pisanja in računanja ne morejo 
Glede na odstotek funkcionalno nepismenih lahko zaključimo, da sta tradicionalna šolska vzgoja in izobraževanje na funkcionalno nepismenih doživela svoj labodji spev. Strogi utilitarni pristop, pomanjkanje pedagoških pristopov in osebnega razumevanja so pripeljali do odpora do kakršnegakoli aktivnega vključevanja v družbo (Orechova, Fomitcheva, 2000, str. 138).

samostojno funkcionirati $\mathrm{v}$ vsakdanjem življenju, kaj šele pripomoči k osebnemu in družbenemu razvoju, zato so zelo odvisne od drugih ljudi in s svojim okoljem vzpostavijo tesne socialne vezi s sebi enakimi in najbližjimi osebami. Okolje, v kate-

\section{$\checkmark$ Sloveniji je pri- bližno 70 odstot- kov funkcionalne nepismenosti.} rem delujejo funkcionalno nepismeni, je navadno manj stimulativno tako glede materialnih možnosti kot tudi glede socialne vplivnosti kulturnih izzivov in mobilnosti. Družbeno so izločeni in $\mathrm{v}$ javnosti se pojavljajo le zaradi preživetvenih potreb na delu, $\mathrm{v}$ trgovini s prehrano in podobno.

Izsledki raziskave, ki je pokazala, da je $\mathrm{v}$ Sloveniji približno 70-odstotna funkcionalna nepismenost, kažejo na to, da obstaja

\section{Izobraževanje funkcionalno nepismenih je izobraževanje za kulturo.} velika neenakost $\mathrm{v}$ obvladovanju pisane besede (branja in pisanja) in neenakost $\mathrm{V}$ dostopu do pisne kulture. Takšna neenakost ni od včeraj. Potrebno se je torej vprašati, kdaj se je pričela družba razslojevati po znanju in ne materialnih dobrinah. Že prva opismenjevanja Slovencev, denimo v času Blaža Kumerdeja in opismenjevanje v 19. stoletju s pojavom javnih šol, niso potekala enakomerno. Nekatere socialne skupine in nekatere družbene kategorije so imele že takrat boljši dostop do pisne kulture. Kasneje je ta postala polimorfna, kompleksna, pluralna in danes nihče ne more trditi, da v času svojega šolanja lahko prav vse prebere in razume, da lahko vse napiše. Seveda tisti, ki so bili deležni najdaljšega šolanja, zvečine izhajajo iz okolja, kjer so bili že predniki šolani. Ti imajo znanja in posedujejo spretnosti branja in pisanja, ali še bolje, vajeni so pisane besede in besedil, ki so oblikovno, funkcionalno in tematsko zelo različna. Doma se navadijo na časopise, prebiranje revij in knjige, obiskovanje kulturnih ustanov in širše druženje z ljudmi. Po drugi strani pa, čeprav nekateri posedujejo minimalno bralno in pisno usposobljenost, se prav lahko zgodi, da ne morejo razumeti ali ne morejo napisati nekaterih vrst besedil, ker so premalo razgledani. Ti so funkcionalno nepismeni. Slednje kaže tudi na nerazvitost abstraktnega mišljenja, ki je bistveno v izobraževanju odraslih (Findeisen, 2000, str. 90, 91).

Izkušnje, ki smo si jih pridobili v jezikovnem izobraževanju odraslih s kratko izobrazbeno potjo, so nas navedle na nekatera spoznanja o tem, kako se takšni odrasli učijo. Omenili smo že kulturno in socialno neenakost, ki se pri takšnih odraslih študentih kaže v številnih kulturnih pomanjkljivostih. Tako se mora usposabljanje malo izobraženih odraslih, če naj z njim dosežemo vsaj nekakšno kognitivno, čustveno in kulturno transformacijo študentov, spremeniti $\mathrm{v}$ izobraževanje in hkratno »kulturno usposabljanje« ali razvijanje usposobljenosti za kulturo. To je moč doseči le na nenasilen, igriv način in z uporabo številnih virov: vizualnih, slušnih in šele nazadnje tudi pisnih. Študente je potrebno varno voditi $\mathrm{v}$ odkrivanje sveta, širšega od onega, ki so ga spoznali dotlej. Izobraževanje, ki bi bilo usmerjeno predvsem $\mathrm{v}$ tematiko in ne $\mathrm{v}$ čustveno preobrazbo človeka oziroma kulturo, bi ostalo brez posledic. Izobraževanje funkcionalno 


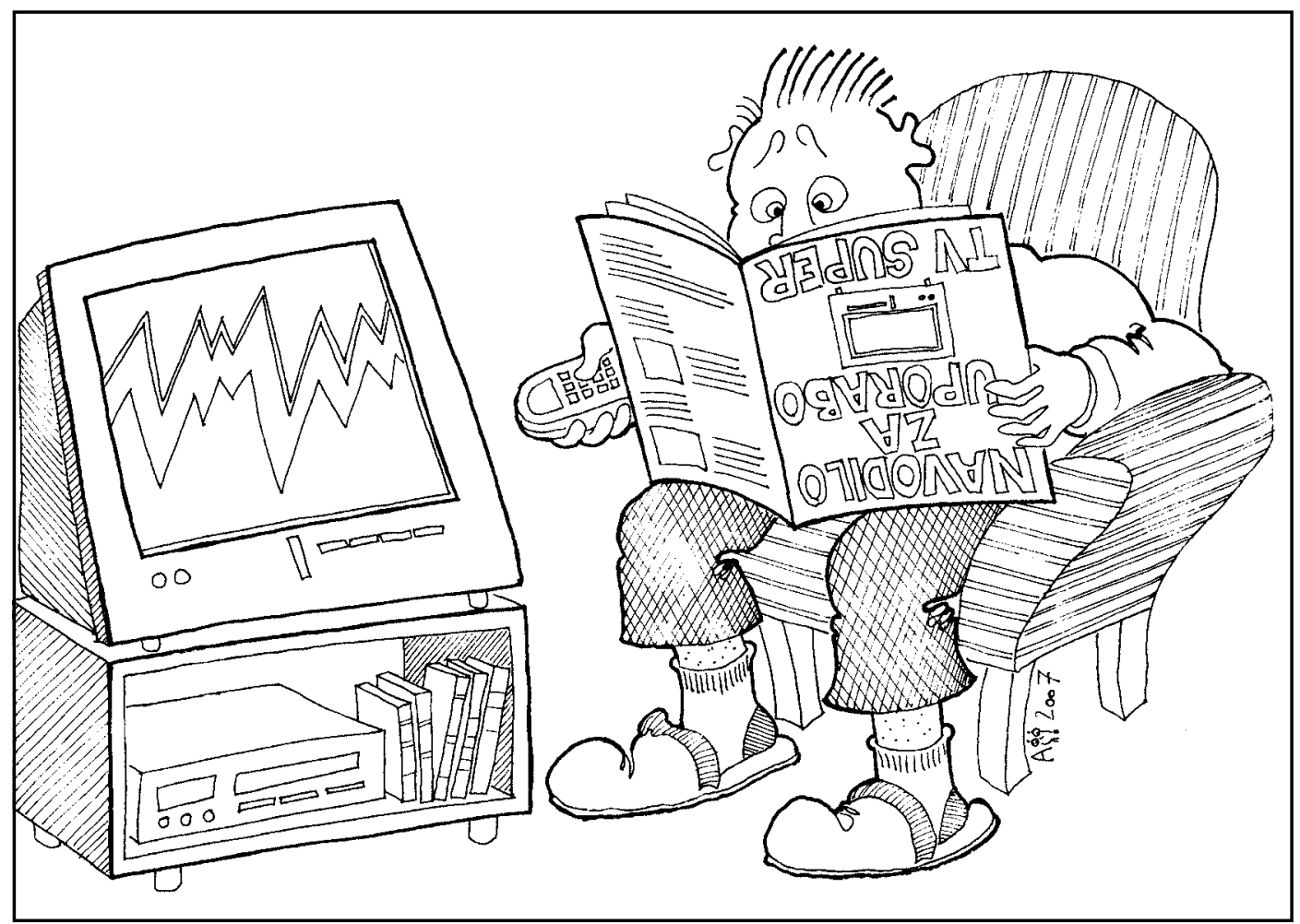

nepismenih je torej izobraževanje za kulturo (Findeisen, 2000, str. 90, 91).

Biti funkcionalno nepismen je $\mathrm{v}$ mnogočem tudi posledica vrednot, ki vladajo $\mathrm{v}$ socialnem okolju, v katerem rastemo. V okolju, kjer znanje ni cenjeno ali ni bilo cenjeno, kjer je moč zadovoljivo preživeti na mnoge druge načine, tudi pridobivanje znanja in pismenosti nima kaj dosti veljave. Funkcionalno nepismen človek ne išče rešitev za svoje življenje $\mathrm{v}$ branju, razumevanju in uporabi besedil, pomaga si zgolj z ljudmi, pa čeprav so ti navadno iz istega socialnega kroga in je tako njihova pomoč omejena (Findeisen, 2000, str. 91).

Pri funkcionalno nepismenih posameznikih se kaže nižja stopnja osebnostnega razvoja in zdi se, kot bi bili ljudje šele na začetku svoje razvojne poti, čeprav so stari že skoraj 40 ali 50 let in več. Od drugih razvitejših posameznikov jih ločujejo večja pasivnost, odvisnost od drugih, podrejanje avtorite- tam, posnemanje močnejših in pomanjkanje lastnih zamisli, nerazviti in ozki interesi, nerazgledanost, subjektivno ocenjevanje dogodkov in stvari $\mathrm{v}$ okolju, nagnjenje $\mathrm{h}$ kratkoročnim ciljem in impulzivno reagiranje v konfliktnih situacijah (Krajnc, 2001, str. 61).

Potrebno je poudariti, da gre pri funkcionalni nepismenosti še za mnogo več kot zgolj za pismenost, ki posamezniku omogoča, da lahko prebere svoje ime, se ne izgubi na ulici in je zmožen na volilnem listku prebrati ime stranke, ki jo voli. Pomembno je to, da lahko napiše svoje ime na mesto, ki mu v družbi pripada, da je zmožen spremljati potek ulice, in določati, kaj bo ta ali ona politična stranka in družba $v$ celoti počela. Torej ne gre le za delovno, politično in socialno socializacijo, ampak za znanje na višjem nivoju: za socialno in akcijsko kompetenco. To pomeni, da človek obvlada spretnosti, ki mu omogočajo uspešno vključevanje v socialno 
okolje in je zmožen aktivno spreminjati kakovost svojega okolja (Hanžek, 2000, str. 93).

\section{DEJAVNIKI FUNKCIONALNE NEPISMENOSTI}

Razmah industrijskega dela je potreboval neizobražene ljudi. Večina prebivalstva je tvorila spodnji del družbene piramide. Trajno brezposelni (funkcionalno nepismeni)

Funkcionalno nepismeni posamezniki tvorijo kulturo nemih. se danes čudijo, zakaj so bili za tovarno dobri dvajset let, sedaj pa jih nihče ne mara. Dolgoročno se omenjeni vplivi izražajo tudi na osebnostnih in vedenjskih potezah. Opazna je močna socialna kontrola vedenja: postanejo čedalje bolj zadržani, nesamozavestni, negotovi, predani pasivnosti, boječnosti itd. Zlasti slednja značilnost se kaže v pretirani odvisnosti in podredljivosti. Freire jo imenuje »kultura nemih« (Nolimal, 2000, str. 6).

Pred nekaj leti se je v Sloveniji v povezavi s funkcionalno nepismenostjo največ govorilo o tem, ali znajo ljudje izpolniti položnice, prebrati in razumeti časopisna sporočila, vozni red in podobno. Danes že $v$ javnosti vztrajamo pri tem, da bi moral vsak posameznik biti sposoben razumno uporabljati zdravila, samostojno ravnati s svojim denarjem (pri pridobivanju in uporabi), uporabljati računalnik, voziti avto, govoriti tuj jezik, se samozaposliti itd. Včasih se še sprašujemo, ali je delo z računalnikom že del naše funkcionalne pismenosti ali še ne. Če danes še ni med merili funkcionalne pismenosti, bo zagotovo kmalu, ker življenje vse bolj poteka po nevidnih poteh računalništva in postajamo vsi odvisni od njega. Koliko je v določeni družbi funkcionalno nepismenih ljudi, je odvisno od zahtevnosti meril, ki smo si jih izbrali. Vsekakor pa te ne morejo zdrkniti niže od potreb za osnovno sporazumevanje z okoljem (Krajnc, 2001, str. 64).

Za funkcionalno nepismenost so odgovorni tako industrijsko razdrobljeno in množično delo s poenostavljenimi delovnimi operacijami, industrijskemu delu prilagojen konzervativen šolski sistem kot tudi razvito ali nerazvito izobraževanje odraslih, stopnja razvitosti kulturnih dejavnosti in stopnja socialnega razvoja, ki odpira (ali pa tudi ne) razne možne oblike združevanja ljudi med seboj $\mathrm{v}$ društvih in drugih interesnih skupinah. Problem funkcionalne nepismenosti je kompleksen, saj morata kultura in socialni razvoj sproti ustvarjati potrebe po znanju, omogočati njihovo zadovoljevanje ter dajati pogoje za kvalitetnejšo raven življenja, ki bo spodbujala nove vzorce aktivnosti med ljudmi.

Funkcionalna nepismenost je usedlina industrijske družbe in se tudi trdovratno zadržuje $\mathrm{v}$ razvitih deželah in $\mathrm{v}$ deželah $\mathrm{v}$ razvoju. Industrijska družba je poudarjala predvsem materialne dobrine (ekonomski razvoj, de-

Med vzroke funkcionalne nepismenosti lahko prištevamo: pomanjkljivo šolanje, pomanjkanje prakse, s katero bi pridobljene spretnosti in znanje pozneje lahko še dovolj pogosto uporabljali, socialno in kulturno zaostalost, ki omejuje način osebnega življenja teh ljudi na osnovne eksistenčne potrebe in njihovo zadovoljevanje, skromne ali slabe materialne možnosti in pomanjkanje objektivnih možnosti za večje aktivnosti, pomanjkanje socialnega kapitala teh ljudi in zelo omejena geografska mobilnost. Dejavniki delujejo v začaranem krogu, ker eden drugega pogojujejo. Le vložen začetni napor, s katerim se človeka ponovno vključi v izobraževanje in se mu hkrati omogoči način življenja, ki bo socialno in kulturno na višji ravni, omogoči, da se ta začarani krog prekine. 
nar, materialne dobrine) in zapostavljala kulturne in socialne dobrine neke družbe. Tako so se pogoji za to, da bi se najgloblje človekove kvalitete razvijale in ohranjale, vedno bolj zmanjševali. Vsi vemo, da ima ameriški ali nemški delavec veliko denarja, da pa njegova kvaliteta življenja ni veliko boljša od tistih delavcev $\mathrm{z}$ malo denarja, ker so ostali kljub denarju v kulturnem getu (Krajnc, 1988, str. 155).

\section{REŠEVANJE PROBLEMA FUNKCIONALNE NEPISMENOSTI}

\section{Delovati za ljudi}

Funkcionalno nepismeni ljudje skrivajo svoje težave, neradi sprašujejo in večino vprašanj in dvomov zadržijo v sebi. Gre za populacijo ljudi $\mathrm{z}$ nizko samopodobo in $\mathrm{s}$ slabimi izkušnjami $\mathrm{v}$ procesu formalnega izobraževanja. Procesa dviga funkcionalne pismenosti smo se v Sloveniji lotili že kmalu po osamosvojitvi $\mathrm{z}$ razvojem projekta Usposabljanje za življenjsko uspešnost (UŽU), kjer se jedro programa nanaša na pridobivanje temeljnih spretnosti, povezanih s funkcionalno pismenostjo (branje, pisanje, računanje), socialnih spretnosti, načel vseživljenjskega učenja, računalništva in aktivnega državljanstva. Program je namenjen predvsem odraslim brezposelnim brez strokovne in poklicne izobrazbe, ki se jih želi usposobiti in motivirati za dejavnejše in kakovostnejše življenje ter jim povečati možnosti na trgu dela. Pri tem je potrebno poudariti, da se $\mathrm{z}$ omenjenimi programi in $\mathrm{z}$ vzpostavitvijo mreže svetovalnih središč, poglobljenim individualnim pristopom in aktivnim iskanjem rešitev povečuje zanimanje za izobraževanje, s tem pa se po eni strani zapolnjujejo vrzeli na področju deficitarnih poklicev, po drugi strani pa poteka proces socializacije in širjenja socialne mreže, poveča se občutek družbene pripadnosti in kulturne identitete, kar vodi do večje samostojnosti in angažiranosti $\mathrm{v}$ družbi. $\mathrm{V}$ prihodnje bi bila potrebna večja usklajenost delovanja centrov za socialno delo in centrov za izobraževanje.

\section{IZBOLJŠATI DOSTOPNOST DO IZOBRAŽEVANIA NA VSEH RAVNEH}

Slovenija je bila edina republika $\mathrm{v}$ nekdanji Jugoslaviji, kjer je bila osnovna šola za odrasle brezplačna. Financirala jo je republiška oblast. To odločitev je izbojevala takratna predsednica Zveze delavskih univerz Slovenije, Tilka Blaha. Z uveljavljanjem programa Osnovne šole za odrasle se v Sloveniji naglo povečuje odstotek ljudi z osnovnošolsko izobrazbo. Ti posamezniki se potem $\mathrm{s}$ pomočjo svetovalnih središč, centrov za informiranje in

Za odpravljanje
funkcionalne
nepismenosti je
nujna povezava
med centri za
socialno delo in
izobraževalnimi
organizacijami.
poklicno svetovanje vključujejo $\mathrm{v}$ nadaljnje izobraževalne programe do pridobitve osnovnega poklica. Srednja šola za odrasle pa je do današnjih dni ostala plačniška, pri rednih programih pa mlade selekcionirajo s številom doseženih točk šolskega uspeha, kar bistveno zmanjša dostopnost do šolanja mladini in odraslim.

\section{DOSEČI REZULTATE V ZAPOSLOVANJU}

Cilj delovanja za funkcionalno nepismene je tudi odzvati se na potrebe družbene in poklicne reintegracije teh oseb. Dati čim več možnosti tem osebam takrat, ko iščejo delo. Potrebno je organizirati regionalna srečanja, ki delodajalce opozarjajo na potrebe po izobraževanju najmanj kvali- 
$\mathrm{V}$ razvitih državah $\mathrm{k}$ stalnosti okolja precej pripomore razvita računalniško vodena industrija, ki ljudi razbremeni fizično najtežjih in najenostavnejših del ter tako krepko oblikuje in določa življenje ljudi. Ko industrija usiha in se država vključi v tokove globalizacije informacijske družbe, pa funkcionalno nepismeni ljudje onemogočajo ali zavirajo razvoj. Ti so trajno nezaposljivi, saj nimajo splošne usposobljenosti za pridobivanje novih poklicnih spretnosti in za prilagajanje velikemu številu hkratnih sprememb. Zanje je potrebno uvesti temeljno izobraževanje. Pri tem ne gre za neke minimalne spretnosti. Prej je mišljeno kot temeljna struktura za prenašanje znanja.

ficiranih delavcev (Findeisen, 1998, str. 22). Procesi globalizacije trga narekujejo izobraževanje na delovnem mestu, s čimer se povečuje konkurenčnost in dodana vrednost delovnega mesta. Posameznik se na ta način prilagaja trgu dela, pridobiva nova znanja in napreduje na osebnostnem področju. Potrebno mu je nuditi možnosti vseživljenjskega izobraževanja skozi vsa življenjska obdobja. Evropski trendi kažejo, da se bo delovna doba podaljšala tudi $\mathrm{v}$ Sloveniji, zato bi bilo potrebno razmisliti o dodatnih motivacijskih in novih oblikah izobraževanja za ljudi v sklepnem delovnem

Avtonomno razmišljanje je nosilec razvoja 21. stoletja. obdobju, ko so znaki izgorevanja v posameznih primerih in poklicih več kot očitni.

Svetovna situacija nas sili, da se oprimemo računalniško opremljene proizvodnje, da od kvantitete proizvodnje preidemo $\mathrm{h}$ kvaliteti proizvodnje in dela sploh, pa tudi h kvaliteti življenja. Svetovni procesi nosijo tudi nas za seboj. Odpravljanje naše domače funkcionalne nepismenosti postaja eden od pogojev našega celotnega preživetja.

Odpravljanje nepismenosti in tudi funkcionalne nepismenosti pomeni preobrat $\mathrm{v}$ naših osnovnih vrednotah. Ponovno bi ena od temeljnih vrednot moral postati človek, ker ga tako postavlja $\mathrm{v}$ centralni položaj tudi sodobna proizvodnja. Vse je odvisno od človeka. Prestrukturiranje vrednot bi pospešilo socialni in kulturni razvoj in ta bi se kmalu odražal tudi v proizvodnji, sodobni kvaliteti dela, ker bi se značilnosti naše populacije dovolj hitro spreminjale. Odpravljanje funkcionalne nepismenosti je vstopnica tudi za modernizacijo slovenskega gospodarstva ter za odgovoren socialni in politični razvoj (Krajnc, str. 187).

\section{ZAKLJUČEK}

Pojav informacijske družbe in s tem tudi globalizacije se je s potrebo po reševanju funkcionalne nepismenosti dotaknil tudi Slovenije. Nagel razvoj družbe, interaktivno komuniciranje preko svetovnega spleta in vrsta novih možnosti zaposlitev in zadovoljevanja osebnih potreb so prisilile posameznika na vseživljenjsko izobraževanje. Masovno proizvodnjo nadomešča vse večje število fleksibilnih malih proizvodnih enot in spretnih posameznikov, osredotočenih na prodajo »blagovne znamke«, na uveljavljanje lastnih zamisli in ustvarjalnega dela. Po velikih političnih spremembah pri nas preživljamo še krče potrošniške družbe in zelo postopoma prepoznavamo razlike med »imeti« in »biti«, kot pravi Erich Fromm v svojem istoimenskem delu. Prav na tem mestu je vloga posameznika zelo pomembna. Avtonomno mišljenje in kritična presoja sta nosilca razvoja 21. stoletja, funkcionalna pismenost pa nam omogoča, da to pot šele začnemo.

Mobilno in fleksibilno prebivalstvo je tisto, ki omogoča hitrejši razvoj regije. Prav zato 
je v dobi globalizacije še kako pomemben človeški kapital in znanje, ki ga je potrebno prilagajati določenim situacijam. Po eni strani smo tako vedno aktivno vključeni $\mathrm{v}$ osebnostni razvoj, po drugi strani pa postanemo tako imenovana blagovna znamka, najpogosteje iskana na trgu delovne sile (Mateju, 2000, str. 43).

Funkcionalna nepismenost je ena temeljnih ovir za uveljavljanje informacijske družbe tudi pri nas. Pri tem ne gre zgolj za pasivno držo posameznika, ampak za socialno, kulturno in politično izključenost ter še vedno prevladujoč centralistični politični in družbeni sistem z omejenimi kompetencami občin in neformalnih skupin. Še več, oseba je pogosto $v$ nerazvitem okolju prepuščena monotonemu vsakdanu, nemotiviranosti na delovnem mestu, družini ali zelo ozkemu krogu posameznikov. Problem funkcionalne pismenosti je tako zelo kompleksen, saj morata kultura in socialni razvoj sproti ustvarjati potrebe po znanju in omogočati njihovo zadovoljevanje ter dajati pogoje za kvalitetnejšo raven življenja, ki bo spodbujala nove vzorce aktivnosti med ljudmi (Krajnc, Prinčič Zajc, 1988, str. 155). V ta namen je treba izboljšati infrastrukturo (razširiti mrežo šol, izobraževalnih središč, knjižnic ...), ponuditi več splošnih in specifičnih oblik izobraževanja za starše, starejše odrasle, prilagoditi programe in slediti tehnološkim novostim, zmanjševati socialne razlike itd. Človek v informacijski družbi lahko unovči samo sebe. Skrbi predvsem za svoj razvoj in se le omejeno obremenjuje $\mathrm{z}$ materialnimi dobrinami. Zavedati se je treba, da nobeno znanje ni večno in da, če ga ne uporabljamo in razvijamo, izgine.

\section{LITERATURA}

Findeisen, D. (1998). Funkcionalna nepismenost in kako jo rešujejo Francozi. Andragoška spoznanja, $3-4$, str. 22.
Findeisen, D. (2000). Kdo so danes nepismeni odrasli in njihove značilnosti $\mathrm{v}$ izobraževanju? $\mathrm{V}$ Pečar (ur.), Pismenost, participacija in družba znanja. 4. andragoški kolokvij. Andragoški center Republike Slovenije, str. 90-92.

Fomitcheva, Z., Orechova, E. (2000). Functional illiteracy in a contemporary society. V Pečar (ur.), Pismenost, participacija in družba znanja. 4. andragoški kolokvij: Andragoški center Republike Slovenije, str. 138-139.

www.acs.si.

Hanžek, M. (2000). Znanje in revščina. V Pečar (ur.), Pismenost, participacija in družba znanja. 4. andragoški kolokvij. Andragoški center Republike Slovenije, str. 93-97.

Krajnc, A., Prinčič Zajc, B. (1988). Analiza funkcionalne nepismenosti v Sloveniji. Sodobna pedagogika, $3 / 4$, str. $147-158$.

Krajnc, A. (2001). Kaj poraja funkcionalno nepismenost: prva opozorila na funkcionalno nepismenost v Sloveniji. Andragoška spoznanja, 1, str. 58-67.

Mateju, P. (2000). Competitiveness and Human Capital. V Pečar (ur.), Pismenost, participacija in družba znanja. 4. andragoški kolokvij: Andragoški center Republike Slovenije, str. 42-58.

Možina, E. (1999). Koliko je funkcionalno nepismenih v Sloveniji. Andragoška spoznanja, 1, str. 13.

Možina, E. (2000). Pismenost odraslih v Sloveniji - pozabljeni kapital. V Pečar (ur.), Pismenost, participacija in družba znanja. 4. andragoški kolokvij: Andragoški center Republike Slovenije, str. 18-41.

Nolimal, F. (2000). Funkcionalna pismenost. Andragoška spoznanja, 3, str. 6.

Spreizer, J. A. (1998). Funkcionalna pismenost na prelomu tisočletja. Andragoška spoznanja, 3-4, str. 9. 